\title{
Multifunctional materials for bone cancer treatment
}

This article was published in the following Dove Press journal:

International Journal of Nanomedicine

28 May 2014

Number of times this article has been viewed

\section{Catarina Marques' \\ José MF Ferreira' \\ Ecaterina Andronescu ${ }^{2}$ \\ Denisa Ficai ${ }^{2}$ \\ Maria Sonmez ${ }^{3}$ \\ Anton Ficai ${ }^{2}$ \\ 'Department of Materials and Ceramics Engineering, Centre for Research in Ceramics and Composite Materials, University of Aveiro, \\ Aveiro, Portugal; ${ }^{2}$ Faculty of Applied Chemistry and Material Science, University Politehnica of Bucharest, Bucharest, Romania; ${ }^{3}$ National Research and Development Institute for Textiles and Leather, Bucharest, Romania}

Correspondence: Anton Ficai Faculty of Applied Chemistry and Material Science, University Politehnica of Bucharest, I-7 Polizu Street, Bucharest 011061 , Romania

Email anton.ficai@upb.ro
Abstract: The purpose of this review is to present the most recent findings in bone tissue engineering. Special attention is given to multifunctional materials based on collagen and collagen-hydroxyapatite composites used for skin and bone cancer treatments. The multifunctionality of these materials was obtained by adding to the base regenerative grafts proper components, such as ferrites (magnetite being the most important representative), cytostatics (cisplatin, carboplatin, vincristine, methotrexate, paclitaxel, doxorubicin), silver nanoparticles, antibiotics (anthracyclines, geldanamycin), and/or analgesics (ibuprofen, fentanyl). The suitability of complex systems for the intended applications was systematically analyzed. The developmental possibilities of multifunctional materials with regenerative and curative roles (antitumoral as well as pain management) in the field of skin and bone cancer treatment are discussed. It is worth mentioning that better materials are likely to be developed by combining conventional and unconventional experimental strategies.

Keywords: bone graft, cancer, collagen, magnetite, cytostatics, silver

\section{Introduction}

Bone is one of the naturally occurring composite materials that still does not have an artificial correspondent. ${ }^{1}$ The interdependence between its morphology and properties is well understood, and two types of bone structures - cortical (compact) and trabecular (spongy) - can be easily identified. These different morphologies seem to be induced by piezoelectricity, with cortical bone being a result of a mechanically assisted biomineralization process. ${ }^{2}$ The arrangement of osteons along with the loading direction can be explained by piezoelectricity. Recently, Noris-Suárez et al reproduced natural biomineralization conditions in vitro. They proved that the mechanical loading of the collagenous material induces important modifications upon the mineral-deposition process. They demonstrated that once mechanical loading takes place, the collagen fibers became arched and the negative charges appear especially distributed on the compressed zones. This is why mineralization occurs predominantly on the compressed areas, even if no osteoblasts are present. ${ }^{3}$

Tissue engineering is of interest for researchers especially because of the increasing need for grafting materials. ${ }^{4}$ The starting monolithic materials have been continuously improved by adding different components aimed at inducing new properties or to improve existing ones. ${ }^{5-9}$ The most common improvements have been related to the increase of healing rate, biocompatibility, or mechanical properties, or with the inducing of new properties, such as antimicrobial, anti-inflammatory, or analgesic activity. These new properties are sought after to avoid certain undesirable side effects or infections. ${ }^{7,-11}$ 
The complex composition and morphology of bone tissues confers them remarkable properties and functionalities. ${ }^{1,12-14}$ In the last few decades, many researchers have invested their efforts in developing new materials for bone grafting inspired in bone composition and structure. ${ }^{15}$ The compositions of bone and some of the most studied bone grafts are presented in Table 1 . The systematic study of bone grafts can be considered to have started in the early twentieth century, when different transplants were done (allografts and xenografts). ${ }^{16}$ Nowadays, special attention is paid to the synthesis of new bone grafts based on composite (nano)materials. Also, many papers deal with the important issue of how to design these materials in order to obtain improved biological properties. Biocompatibility and biointegration are usually realized by using engineered composite (nano)materials starting from natural polymers, calcium phosphates, and bone cells.,

Based on the classification made by Ashby et al, ${ }^{17}$ nowadays there is a gradual transition occurring from the "nano- and bio-" age to a material-design age. During the nano- and bioage, scientists focused their attention on improving material properties by decreasing materials' size to the nanometric scale, but also paid attention to improving biological assessment in order to be better accepted by the human and animal body. ${ }^{18}$ The material-design age maintains this principal concern, but improvements are achieved by optimizing such material characteristics as porosity, hydrophilicity, pore size, distribution, and shape, etc. ${ }^{19,20}$ This is why there are a lot of papers dealing with material design or tissue-engineered nanobiomaterials,

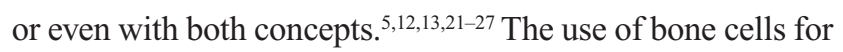

Table I Composition of bone and its substitutes

\begin{tabular}{|c|c|}
\hline $\mathrm{Bone}^{28,29}$ & $\begin{array}{l}50-74 \text { wt } \% \text { mineral phase; mainly } \mathrm{HA} 45 \%-58 \%, \\
\text { carbonate } \sim 4 \% \text {, citrate } \sim 0.9 \% \text {, sodium } \sim 0.7 \%, \\
\text { magnesium } \sim 0.5 \% \text {, but also many other trace } \\
\text { elements, such as } \mathrm{Cl}^{-}, \mathrm{F}^{-}, \mathrm{K}^{+}, \mathrm{Sr}^{2+}, \mathrm{Pb}^{2+}, \mathrm{Zn}^{2+}, \mathrm{Cu}^{2+} \text {, } \\
\mathrm{Fe}^{2+} ; 16-40 \text { wt\% organic ( } 85 \%-90 \% \text { collagen); } \\
<10 \text { wt } \% \text { water }\end{array}$ \\
\hline Substitutes ${ }^{29-35}$ & $\begin{array}{l}\text { Metals and alloys (first-generation bone grafts): } \\
\text { titanium and its alloys, stainless steel, } \mathrm{Co}-\mathrm{Cr} \text { alloys } \\
\text { Ceramics and polymers (second-generation bone } \\
\text { grafts): calcium phosphates, } \mathrm{Al}_{2} \mathrm{O}_{3}, \mathrm{ZrO}_{2} \text {; collagen, } \\
\text { gelatin, chitosan, chitin, alginate, PLLA, PLGA, } \\
\text { PVA, PMMA, PE, PCL } \\
\text { (Nano)composite (third-acellular materials and } \\
\text { fourth-generation bone grafts, containing cells } \\
\text { or derived): COLL/HA, HA/gelatin, HA/chitosan, } \\
\text { HA/alginate, HA/PLGA, HA/PLLA, HA/PE, } \\
\text { HA/PVA, COLL/PVA/HA }\end{array}$ \\
\hline
\end{tabular}

Abbreviations: COLL, collagen; HA, hydroxyapatite; PVA, polyvinyl alcohol; wt, weight; PLGA, polylactide-co-glycolide; PMMA, polymethyl methacrylate; PE,

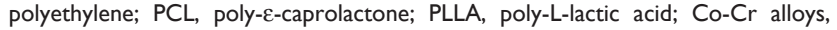
Cobalt-Chrom alloys. obtaining bone grafts could bring some major advantages: 1) the cells could be gathered from the patient and cultured in vitro; 2) the opportunity for using available stem cells that can be differentiated under proper conditions into bone cells; and 3) bone graft seeded with bone cells has the ability of being easily invaded by new bone ingrowth, thus promoting a much faster integration and the achievement of natural bone properties in a shorter time, in safe conditions, and with less donor tissue compared with classical auto- and allografting procedures. ${ }^{36,37}$ Moreover, the bone graft can act as a drug-delivery system for antibiotics and consequently enhance bone ingrowth in conjunction with wound healing. ${ }^{37}$

Worldwide, cancer remains the second-most common cause of death, despite the advances in prevention, early detection, and protocols of treatment. It is well known that pain continues to be the most feared complication during treatment. ${ }^{38-40}$ In 2008, the total number of new cancer cases, based on the International Agency for Research on Cancer, was 12,662,554 (52.26\% men), while for $2030 \sim 21$ million new cases of cancer are expected. ${ }^{41}$ Mortality is strongly influenced by cancer type. The overall or mortality numbers worldwide in 2008 were 7,564,802 ( 59.75\% of total incidence). Among the cancer types, the best survival rates (mortality/incidence $\times 100$ ) are for thyroid and testis cancer (16\% and $18 \%$, respectively), while the worst are for liver and pancreas cancer (93\% and 96\%, respectively). ${ }^{42}$ The very low survival rate is probably strongly influenced by the high mortality induced by lung cancer (which accounts for $\sim 18.2 \%$ of total cancer mortalities). ${ }^{43}$

Cancer usually occurs in mature/old people, except osteosarcoma, which is typically diagnosed in young people (10-20 years old) and rarely in old people, ${ }^{44,45}$ in the extremity of the long bones, especially in the femur. ${ }^{46}$ There are 45 main types of primary bone tumor, the most important being osteosarcoma (35.1\% of the primary bone tumors), followed by chondrosarcoma, Ewing's sarcoma, and chondroma. By sex, males are more exposed to bone cancer (4\% incidence in males compared to $3 \%$ in females), ${ }^{47}$ even though osteosarcoma develops earlier in females compared with males (by about 2 years). ${ }^{46}$

Cancer treatment is mainly based on surgery and radioand chemotherapy, but also other unconventional therapies are available: hyperthermia, targeted therapy, immuno- or phototherapy, the use of nanoparticles or stem cell transplants, or many other less used therapies. ${ }^{48}$ Hyperthermia is being used more and more as complementary therapy. The main result of the application of this therapy is decreasing chemotherapeutic doses or levels of radiation needed to 
maintain or even improve the efficiency of the treatment. ${ }^{49-51}$ Also, the use of nanoparticles showed a significant antitumoral effect, alone or in association with other therapies. ${ }^{52-55}$ These alternative therapies are mostly in the experimental phase of research, present an exciting challenge for the present, and will probably offer solutions for cancer treatment in the future, but there are also some alternative therapies currently available for cancer treatment, such as Doxil ${ }^{\circledR}$ (Janssen, Beerse, Belgium) and Abraxane ${ }^{\circledR}$ (Celgene, Summit, NJ, USA). ${ }^{55}$

Drug-delivery systems are also used for different kinds of cancer. The most popular drug-delivery systems are based on polymers and ceramics and their composites. Polymers are by far the most used drug-delivery systems, the most used being polyethylene glycol (PEG), polyethylene oxide, poly$\varepsilon$-caprolactone, chitosan, alginate, polyvinyl alcohol (PVA), polymethyl methacrylate, cellulose, etc. ${ }^{56-67}$ Also, proteins (collagen being the most abundant) are known as support for drug-delivery systems, but usually their high chemical and physical instability present technical problems related to synthesis and storage. ${ }^{68-71}$ PVA is extremely useful for chemoembolization, and in certain conditions can be loaded with various antitumoral drugs, such as cisplatin, doxorubicin, mitomycin $\mathrm{C}$, and ethiodol. ${ }^{67,72-74}$ Ceramic drug-delivery systems are also used for the treatment of bone cancer. ${ }^{75}$

\section{Collagen-hydroxyapatite composite materials}

Collagen is a special class of proteins present in many tissues and organs. The history of collagen starts in 1960 with the discovery of the first representative of this class. Currently, 29 types of collagen ${ }^{76}$ are known. From the point of view of distribution and biomedical applications, type I collagen is by far the most abundant and used variety. The intensive use of type I collagen can be easily explained based on the following: 1) there are a large number of type I collagen precursors (especially bovine calf); 2) the extraction technology is convenient (even native, fibrillar collagen is obtained under controlled conditions, collagen being susceptible to denaturation), because of the short extraction time with cheap reactants, especially if compared with the technology of extraction of type $\mathrm{V}$ collagen from bone. ${ }^{77-79}$ In the case of bone, a supplementary step is required, which consists of bone decalcification with hydrochloric acid and/or ethylenediaminetetraacetic acid. ${ }^{80-82}$ Once extracted, the native or denatured collagen can be stored as gel or transformed in fibers or matrices. ${ }^{77}$

It is worth mentioning that type I collagen is also commercially available and used as wound dressing, especially in the case of burns, ${ }^{83,84}$ as a main component of many creams designed for care or treatment of skin laxity, rhytides, or photoaging, ${ }^{85}$ or as a component of many engineered materials used for bone regeneration and cancer treatment. ${ }^{70,78,86,87}$ Collagen has also been used since 1980 as a drug-delivery system for ophthalmic agents (especially the antibiotics gentamicin and vancomycin), ${ }^{88}$ the trend being to extend the use of this material in obtaining many other drug-delivery systems. ${ }^{71,78,89}$

Despite intensive research efforts in the field of bone and bone grafts, ${ }^{29,90-94}$ the properties of the materials obtained are still far from those of healthy bone. ${ }^{95}$ Many types of materials have been separately attempted as bone grafts, such as ceramics ${ }^{32,96,97}$ and polymers, ${ }^{98,99}$ or combined in different manners to obtain composite materials. ${ }^{12,22,23,27,29,93,100-108}$ Collagenhydroxyapatite (COLL/HA) composites are desired materials for bone grafting, especially due to their very good compositional similarity with bone, ${ }^{1,28}$ but also as drug-delivery systems. ${ }^{109-113}$ COLL/HA composite materials are currently extensively used as bone grafts. ${ }^{12,21,33,34,93,100-108,114-117}$ Obviously, the biological properties as well as the mechanical properties are influenced by the manufacturing process. The size and crystallinity of hydroxyapatite crystals are essential parameters that influence the biological properties, ${ }^{95,118}$ materials based on smaller crystals inducing less inflammatory response. ${ }^{95}$

Most studied are the porous COLL/HA composite materials, which could be considered especially for trabecular bone grafting and reconstruction, but can also be used for compact bone reconstruction. The biointegration of COLL/ HA scaffolds is strongly influenced by porosity and pore size. Generally, it can be assumed that 150-200 $\mu \mathrm{m}$ pores are optimal for rapid osteointegration. ${ }^{119}$ Larger pores are unwanted, because the mechanical properties of the graft drastically decrease, while narrower pores limit cell penetration inside the graft. ${ }^{120,121}$ Porosity and pore size can be controlled by different parameters, such as precursor concentration, drying conditions, presence of different components, etc. ${ }^{13,22}$ Usually, COLL/HA composite materials with high porosity are obtained from diluted, mineralized collagen gel followed by freeze-drying. Control of porosity can easily be achieved by controlling the drying process, (eg, air-drying followed by freeze-drying). ${ }^{13}$ It has been proved that porosity decreases upon increase in air-drying time/extent. ${ }^{12,13}$ The explanation is very simple: air-drying is driven by capillary action that makes the material shrink and become denser during the evaporation of liquid water. ${ }^{12}$ Conversely, capillary forces are absent in freeze-drying, which involves sublimation of 
frozen water, therefore maintaining the initial morphology of the porous structure. Based on literature data published by us, ${ }^{13}$ the evolution of the porosity of samples obtained by combined drying is presented in Table 2 , and ranges between $95 \%$ and $38 \%$.

More compact composite materials are usually obtained from collagen gel by mineralization under such conditions that allow continuous material restructuring (Table 2, sample SA, COLL-PVA 1:2 A, or COLL-PVA/HA 1:2:3 A). Porosity can fall below even $5 \%$ if centrifugal sedimentation is used and only then dried in air.

Figure 1 presents the morphology of some COLL/HA composite materials obtained by mineralization of collagen in different forms (gel, matrix, or fiber). ${ }^{12,21,115}$ From collagen gel, both porous and compact materials as well as materials with intermediate porosity can be obtained. The mineralization of collagen matrix usually leads to porous composite materials. Probably, under certain conditions, collagen matrices and fibers can be processed to more compact materials. Porous composite materials have been tested as drug-delivery systems because, similarly with natural bone, the exchange rate (here the release rate) of the porous materials is higher than the release rate from compact materials.

\section{Multifunctional materials}

A lot of materials have been tested as delivery support for bone-related diseases. A short review on this specific topic was recently published by Soundrapandian et al. ${ }^{122}$

Table 2 Influence of preparation route and composition on the porosity of different samples

\begin{tabular}{|c|c|c|}
\hline Sample & Porosity, \% & Observations \\
\hline CAD 0 & 95 & CAD samples obtained \\
\hline CAD 30 & 94 & by controlled air-drying, \\
\hline CAD 48 & 93 & followed by freeze-drying \\
\hline CAD 76 & 92 & Data extracted from \\
\hline CAD 96 & 88 & Andronescu et $\mathrm{al}^{13}$ \\
\hline CAD I73 & 54 & \\
\hline CAD 199 & 38 & \\
\hline$\overline{\mathrm{SA}}$ & 16 & $\begin{array}{l}\text { COLL/HA material obtained } \\
\text { by self-assembly }{ }^{12} \text { (data not } \\
\text { presented in that manuscript) }\end{array}$ \\
\hline COLL-PVA I:2 L & 93 & "L" samples obtained by \\
\hline COLL-PVA I:2 A & 19 & freeze-drying \\
\hline COLL-PVA/HA I:2:3 L & 79 & "A" samples obtained by \\
\hline COLL-PVA/HA I:2:3 A & 14 & $\begin{array}{l}\text { air-drying } \\
\text { Data extracted from Ficai et } \mathrm{al}^{5}\end{array}$ \\
\hline COLL/HA centrifugation & 3 & $\begin{array}{l}\text { COLL/HA material obtained } \\
\text { by mineralization followed } \\
\text { by centrifugal sedimentation } \\
\text { (data not published) }\end{array}$ \\
\hline
\end{tabular}

Abbreviations: COLL, collagen; HA, hydroxyapatite; PVA, polyvinyl alcohol.
Most of these drug-delivery systems are based on the combination of different polymers with bioglass or calcium phosphates. Even if natural polymers are more suitable, a lot of composite materials based on synthetic polymers, such as polycaprolactone, poly(D,L-lactide), polylactide-coglycolide (PLGA), or polymethyl methacrylate, have been also regarded with increasing interest. ${ }^{122-124}$ The enhanced stability of synthetic polymers in comparison with natural ones explains the higher number of composite materials based on synthetic polymer matrices. Further, the possibility of tailoring the composition of synthetic polymers enables a broader range of properties to be obtained for the final composites, including mechanical properties, drug-release rate, etc.

Starting from the well-established materials for bone grafting, different kinds of natural or synthetic components (Table 3) have been added in order to induce some new functionalities. Multifunctional materials are being regarded with increasing interest for both industrial and biomedical applications. ${ }^{125,126}$ The multifunctional features of collagen and COLL/HA composite materials can be induced by the incorporation of various components, such as bone morphogenic protein, ${ }^{127-131}$ vitamins, ${ }^{110,132}$ bisphosphonates, ${ }^{11,133}$ antibiotics, ${ }^{69,112,113}$ magnetite, ${ }^{116}$ cytostatics, ${ }^{70}$ or even more complex systems. ${ }^{134}$ A main functionality of many of these systems is related to their ability to deliver the active component. Perhaps the most studied drug-delivery systems are those loaded with antibiotics or analgesics. ${ }^{134}$ For the treatment of severe bone defects, surgical intervention might be required, because otherwise self-healing would be very slow, or even abnormal repair could happen. ${ }^{29}$ The current protocols in the case of surgical intervention include the administration of antibiotics. A better alternate is to use bone grafts with antibacterial activity (for instance, an antibioticloaded bone graft), because the local delivery of the antibiotic reduces the systemic toxicity of these drugs. ${ }^{135,136}$ The use of analgesic-loaded materials is a real need in the treatment of many diseases. In some cases, drug-loaded systems are easy to apply clinically. For instance, in the case of bone cancer, resection of the tumoral tissue is often required, leaving a bone defect that needs to be filled with bone-regenerative material. Bone fillers can in fact be more complex systems incorporating pharmaceutically active substances (analgesic and/or antitumoral drugs), allowing them to be released in situ. ${ }^{70,134}$ Generally, the presented multifunctional systems were developed in order to assist natural repair mechanisms (bone morphogenic protein presence improves the rate of bone regeneration, bisphosphonate indirectly favors bone formation by suppressing bone resorption) or even to act as 


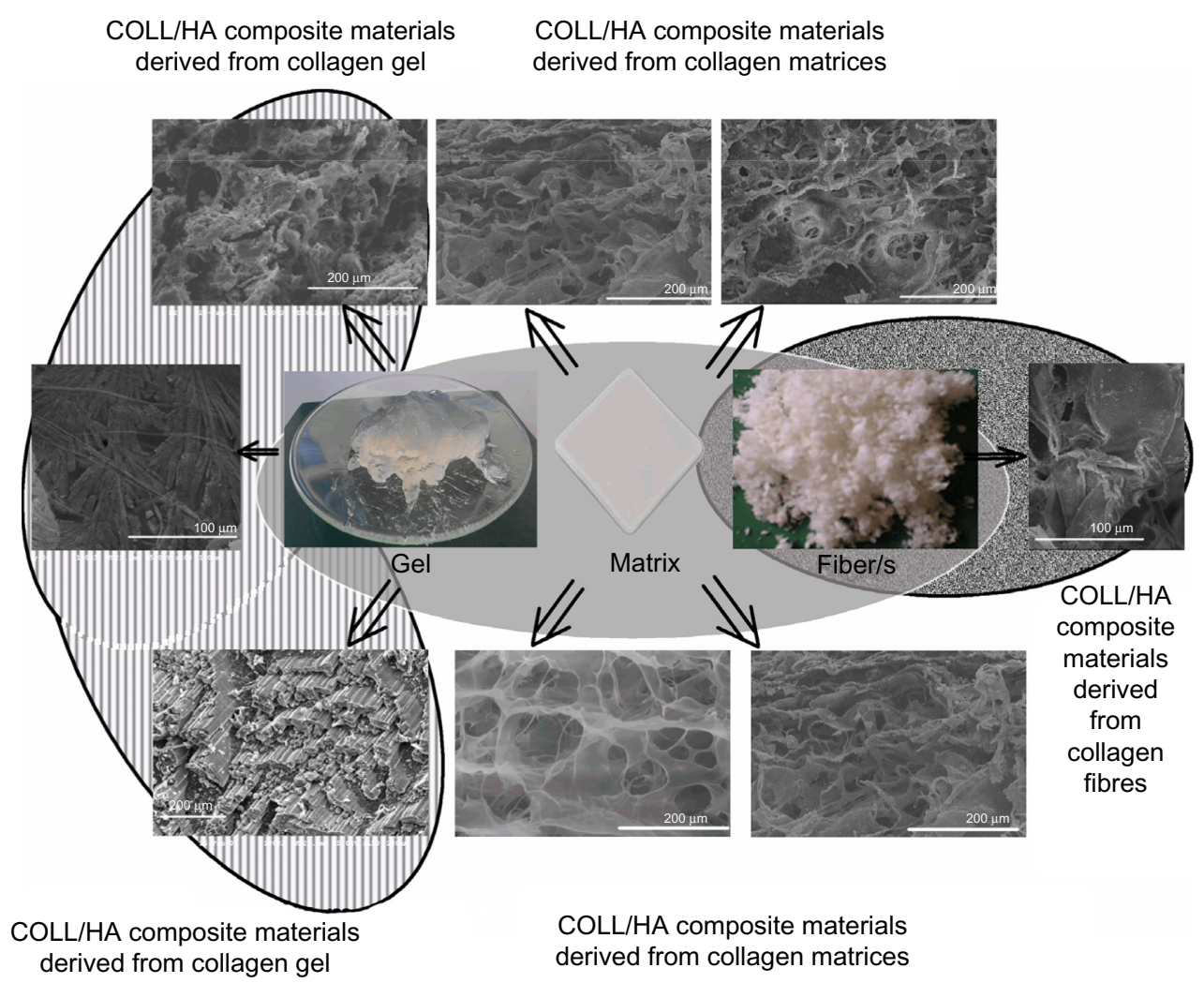

Figure I Collagen (COLL) forms and their COLL/hydroxyapatite (HA) composite (nano)materials.

Notes: Reprinted from Chem Eng J.I60. Ficai A, Andronescu E, Voicu G, et al. Self assembled collagen/ hydroxyapatite composite materials. 794-800. Copyright (20I0), with permission from Elsevier. ${ }^{12}$ Reprinted from Mater Lett. 64. Ficai A, Andronescu E, Trandafir V, Ghitulica C, Voicu G. Collagen/hydroxyapatite composite obtained by electric field orientation. 54I-544. Copyright (2010), with permission from Elsevier. ${ }^{21}$ Adapted from Golub LM. Special Issue: Clinical Applications of Non-Antbacterial Tetracyclines Introduction. Pharmacol Res. 201 I;63:99-101.114

drugs (for avoiding infections [antibiotics] or even to fight against cancer [cytostatics] or other bone-related diseases). All these systems can be assimilated with drug-delivery systems and could be used to treat diseases from simple bone defects/fractures up to bone cancer. It is expected that clinical trials will be positive, because local administration will improve drug efficiency and limit side effects. ${ }^{70,137}$

\section{Drug-delivery systems for bone cancer treatment}

Research on cancer treatment has focused on two main areas: 1) developing new drugs, and 2) improving the activity of existing drugs by reducing their side effects. The main strategy for improving the activity of antitumoral agents is local delivery. A lot of drug-delivery systems were proposed and tested between 1991 and 2013, ${ }^{138}$ such as PLGA/doxorubicin, ${ }^{139}$ chitosan/paclitaxel,${ }^{140}$ polyurethane/ curcumin, ${ }^{141}$ chitosan/ellagic acid, ${ }^{142}$ alginate/cisplatin, ${ }^{62}$ poly-L-lactic acid/paclitaxel, ${ }^{143}$ PLGA/isopropyl myristate/ paclitaxel, ${ }^{143}$ PEG-poly(aspartic acid)/adriamycin,${ }^{144}$ gelatin/doxorubicin, ${ }^{145}$ hydroxyapatite/platinum complexes, ${ }^{146,147}$ or COLL/HA/ cisplatin. $^{70}$
Apatite-based materials are extensively used as bone filler/ grafts. ${ }^{148-150}$ This is why many drug-delivery systems designed for bone-disease treatment are based on hydroxyapatite. For instance, hydroxyapatite/cisplatin drug-delivery systems were obtained and tested as delivery systems of different platinum complexes. ${ }^{147,151-154}$ Many trials were taken into account, focusing on the synthesis route, drug content, porosity, pore size, etc. Hydroxyapatite samples with different porosity fractions $(58 \%, 76 \%$, and $82 \%)$ and average pore sizes $(15 \mu \mathrm{m}, 21 \mu \mathrm{m}$, and $35 \mu \mathrm{m})$ were obtained by the gel-casting method followed by cisplatin loading. ${ }^{147}$ Percentage cisplatin recovery after 168 hours increased from $21 \%$ to $28 \%$ and $42 \%$ as porosity fractions increased within the aforementioned range $(58 \%-82 \%)$. Control of the release rate is of paramount importance, because long-term delivery could decrease cancer recurrence by reducing remnant cancerous cells. ${ }^{70}$

Recently, Abe et al developed new paclitaxel-loaded hydroxyapatite/alginate composite material for the treatment of metastatic spine cancer, ${ }^{153}$ which develops frequently in patients with breast cancer. Based on animal experiments, the use of paclitaxel-loaded hydroxyapatite/alginate composite 
Table 3 Common components used for inducing bone graft multifunctionality

\begin{tabular}{|c|c|c|}
\hline Component & Observations & References \\
\hline Collagen & $\begin{array}{l}\text { Support material for tissue } \\
\text { regeneration (especially } \\
\text { skin-tissue regeneration) }\end{array}$ & 83,84 \\
\hline Hydroxyapatite & $\begin{array}{l}\text { Support material for tissue } \\
\text { regeneration (especially for } \\
\text { bone-tissue regeneration) }\end{array}$ & 95 \\
\hline BMPs & Improve bone regeneration & $\begin{array}{l}|27-13| \\
\mid 55-158\end{array}$ \\
\hline Bisphosphonate & $\begin{array}{l}\text { Synthetic compounds that are } \\
\text { taken up preferentially by the } \\
\text { skeleton and suppress osteoclast- } \\
\text { mediated bone resorption }\end{array}$ & 133,159 \\
\hline Vitamins & $\begin{array}{l}\text { I,25 Dihydroxycholecalciferol } \\
\text { (D3) - calcium homeostasis }\end{array}$ & 160 \\
\hline & $\begin{array}{l}\text { Vitamin } \mathrm{K} \text { - responsible with } \\
\text { bone mineralization }\end{array}$ & $\begin{array}{l}109,132 \\
160\end{array}$ \\
\hline Antibiotics & $\begin{array}{l}\text { Antibacterial purpose } \\
\text { (gentamicin, norfloxacin, } \\
\text { ciprofloxacin, vancomycin) }\end{array}$ & $\begin{array}{l}111,112 \\
161\end{array}$ \\
\hline Analgesics & $\begin{array}{l}\text { Local analgesics are used } \\
\text { especially for pain management }\end{array}$ & 14 \\
\hline Nanoparticles & & \\
\hline Magnetite & $\begin{array}{l}\text { Cancer therapy by hyperthermia } \\
\text { Magnetic resonance imaging } \\
\text { Drug delivery and targeted } \\
\text { delivery }\end{array}$ & $\begin{array}{l}116,162,163 \\
164,165 \\
165-167\end{array}$ \\
\hline Silver & $\begin{array}{l}\text { Antibacterial and antitumoral } \\
\text { effects }\end{array}$ & $168-172$ \\
\hline Cytostatics & Antitumoral effects & $70,173-175$ \\
\hline $\begin{array}{l}\text { Glycosaminoglycans } \\
\text { (hyaluronan and } \\
\text { chondroitin } \\
\text { sulphate) }\end{array}$ & $\begin{array}{l}\text { - modulate the attraction of skin } \\
\text { and bone precursor cells and } \\
\text { their subsequent differentiation } \\
\text { and gene expression } \\
\text { - regulate the action of proteins } \\
\text { essential to bone and skin } \\
\text { regeneration }\end{array}$ & 176,177 \\
\hline
\end{tabular}

beads led to $140 \%-150 \%$ increases in disease-free time as well as survival time compared with control animals.

Itokazu et al developed some drug-delivery systems based on hydroxyapatite and cytostatics for bone cancer treatment. ${ }^{177-179}$ They proved that porosity and pore size influenced the release rate of both doxorubicin and methotrexate. The implantation of these ceramic blocks at the tumor site led to a reduction in dose of the antitumor agent, and consequently the risk of systemic toxicity decreased drastically compared with conventional systemic administration. The improved contact of antitumor agents with tumoral cells is expected to reduce the recurrence and metastasis of cancer.

A gelatin/doxorubicin drug-delivery system ${ }^{145}$ was obtained and tested for the treatment of bone cancer, because doxorubicin is one of the most potent antitumor agents in use for bone cancer treatment, while the gelatin could act, after doxorubicin release, as a scaffold for bone regeneration. The classical administration route of doxorubicin is undesirable because of severe side effects. A general way to reduce side effects is to avoid intravenous administration of antitumor agents by using drug-delivery systems. In the case of bone cancer, the use of implantable gelatin/doxorubicin could be a promising way of targeted delivery of doxorubicin to tumoral tissue. The rate of delivery could be easily controlled by the degree of crosslinking and porosity.

COLL/HA-cisplatin is a remarkable material for the treatment of bone cancer because it assures two functions: targeted delivery of cisplatin and acting as a regenerative scaffold. ${ }^{70}$ For this reason, samples were obtained and tested from the point of view of cisplatin-induced cytotoxicity. The delivery curve of cisplatin has two independent regions: a fast delivery up to 2 hours, followed by a sustained delivery of cisplatin up to 26 hours. ${ }^{70}$ The short release time can be exploited by choosing a proper polychemotherapeutic method that includes the cisplatin release and further traditional administration of complementary cytostatics. ${ }^{181}$

Bone cancer is usually associated with terrible pain. ${ }^{182-184}$ Up to $30 \%$ of patients with recently diagnosed cancers report pain. With the evolution of the cancer, the pain becomes more intense, and about $80 \%$ of patients with primary bone cancer and over $90 \%$ of patients with metastases to osseous structures need ever-stronger drugs for pain management. ${ }^{39,185-187}$ Based on the World Health Organization analysis, pain intensity as well as pain management is classified at three levels. The lowest level of pain is usually treated with nonopioid and/or adjuvant drugs (aspirin and acetaminophen being extensively used), the middle and worst levels of pain need increasing doses of opioids (and also with increasing efficiency from weak [codeine, for instance] to strong opioids [morphine, for instance]) combined or not with nonopioid and/or adjuvant drugs. ${ }^{186}$ In the case of severe pain, systems with immediate or sustained release are used. ${ }^{187}$

\section{Magnetite and magnetite-based materials for bone cancer treatment}

An overview of the most important applications of magnetite and magnetite-based materials is presented in Figure 2. Pure magnetite is rarely used for cancer treatment, in particular because of its high tendency of agglomeration and high reactivity. This is why many researchers have attempted to functionalize its surface from simple fatty acids, ${ }^{188}$ up to 


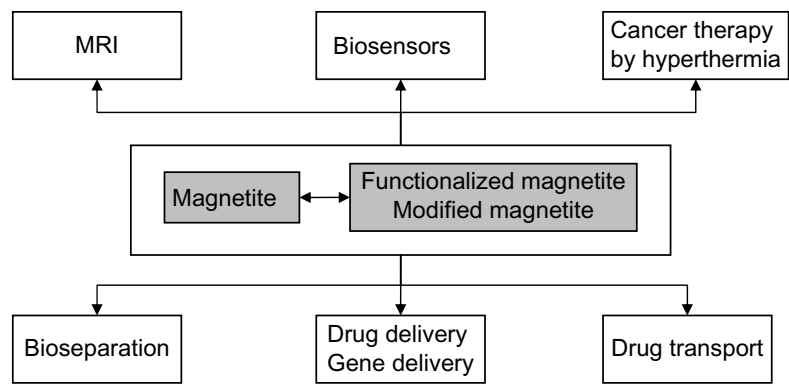

Figure 2 Applications of magnetite and magnetite-based materials. Abbreviation: MRI, magnetic resonance imaging.

complex agents, such as aminophosphonic acid, diols and polyols, polyhydroxy acids, siloxanes, thioacids, etc. ${ }^{189}$ As presented in Figure 2, magnetite and magnetite-based materials are efficient in cancer diagnosis as well as in cancer treatment, including hyperthermia as well as drug transport and targeted delivery. The hyperthermia is produced by magnetite when a proper alternating electromagnetic field is applied. The output power and the applied frequency are essential for producing medical hyperthermia, especially in the case of deep organs/tissues. ${ }^{190}$ Usually, these radiations are of low power and should induce low toxicity. ${ }^{191}$

Magnetic materials proved its effectiveness in the treatment of different diseases, including cancer treatment, by combining surgery - as a conventional treatment and hyperthermia - as an alternate route of treatment. A methodology of treating bone cancer was presented by Andronescu et al, ${ }^{116}$ (Figure 3) and consists of two main parts. The first step is assimilated with the surgical intervention of resection of the tumoral tissue, while the second step consists of filling the resulting bone defect with multifunctional materials. Once implanted, bone healing starts due to the presence of COLL/HA composite material. The magnetic nanoparticles can be activated, externally and at any time, by applying an electromagnetic field that induces hyperthermia.

Even if only a few materials are based on COLL/ $\mathrm{HA}-\mathrm{Fe}_{3} \mathrm{O}_{4},{ }^{116,134}$ perhaps, due to the high sensibility of the collagenous structure, their potential is great. The work realized by Andronescu et al ${ }^{116}$ presents the preparation of different COLL/HA- $\mathrm{Fe}_{3} \mathrm{O}_{4}$ with a 1:4 ratio of COLL:HA and $1 \%, 2 \%$, and $5 \%$ magnetite. The in vitro studies revealed that mild hyperthermia is produced even at low magnetite content. In the case of COLL/HA- $\mathrm{Fe}_{3} \mathrm{O}_{4}$ with $1 \%$ magnetite, the maximum temperature reached was $\sim 41^{\circ} \mathrm{C}$, which means mild hyperthermia, while at 5\% magnetite the maximum temperature exceeded $45^{\circ} \mathrm{C}$ (Figure 4). All these data were obtained using thermostated samples $\left(37^{\circ} \mathrm{C}\right)$ at $150 \mathrm{kHz}$.

The aforementioned methodology of bone cancer treatment can be easily adapted for more complex material drug-delivery systems, such as $\mathrm{COLL} / \mathrm{HA}-\mathrm{Fe}_{3} \mathrm{O}_{4}$-cytostatic, COLL/HA- $\mathrm{Fe}_{3} \mathrm{O}_{4}$-analgesic, $\mathrm{COLL} / \mathrm{HA}-\mathrm{Fe}_{3} \mathrm{O}_{4}-\mathrm{Me}$ $(\mathrm{Me}=\mathrm{Au}, \mathrm{Ag}), \mathrm{COLL} / \mathrm{HA}-\mathrm{Fe}_{3} \mathrm{O}_{4}-\mathrm{Me}-$ cytostatic, $\mathrm{COLL} /$ $\mathrm{HA}-\mathrm{Fe}_{3} \mathrm{O}_{4}-\mathrm{Me}$-analgesic, or even COLL/HA- $-\mathrm{Fe}_{3} \mathrm{O}_{4}-$ $\mathrm{Me}$-analgesic-cytostatic. ${ }^{134}$ These multifunctional materials assure the convergence of conventional (surgery and chemotherapy) and alternative (hyperthermia, antitumoral effect of some metallic nanoparticles, phototherapy, and pain management due to the presence of analgesics) routes of bone cancer treatment. It is expected that due to the unconventional component of bone cancer treatment (as well as the targeted delivery of chemotherapeutic drugs) that the content of chemotherapeutic drugs will decrease and consequently systemic toxicity will be minimized.

For instance, Campbell et al ${ }^{192}$ synthesized quasicubic magnetite/silica core-shell nanoparticles that proved to be enhanced magnetic resonance imaging (MRI) contrast agents for cancer imaging. The synthesis of $\mathrm{Fe}_{3} \mathrm{O}_{4} @ \mathrm{SiO}_{2}$ was performed from prefabricated magnetite nanoparticles by controlled hydrolysis of Tetraethylorthosilicate with the formation of a silica network onto the magnetite nanoparticles. Using these quasicubic magnetite/silica nanoparticles, in vitro and in vivo experiments were carried out. Based on the in vivo experiments on mice infected with PC3 human prostate cancer cells, the change in MRI signal was up to

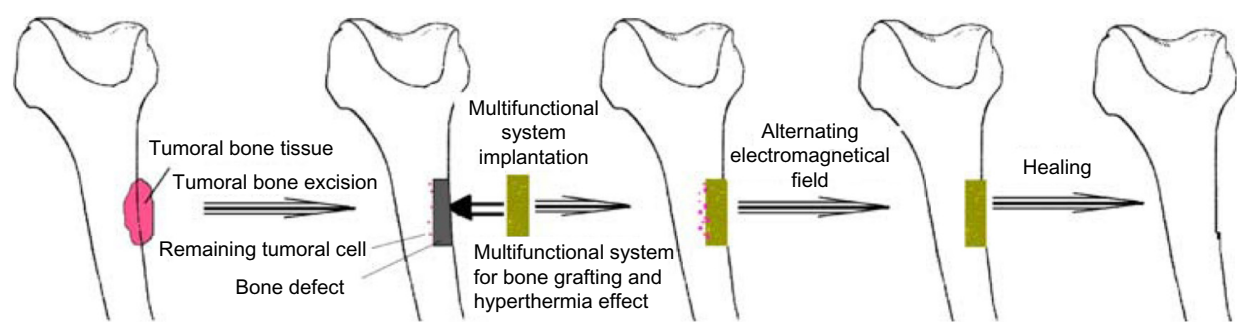

Figure 3 Schematic representation of bone cancer treatment by combined therapy (surgery and hyperthermia).

Note: With kind permission from Springer Science+Business Media: J Mater Sci-Mater M., Synthesis and characterization of collagen/hydroxyapatite:magnetite composite material for bone cancer treatment. 2I, 2010, 2237-2242, Andronescu E, Ficai M, Voicu G, Ficai D, Maganu M, Ficai A, figure 2. ${ }^{116}$ 


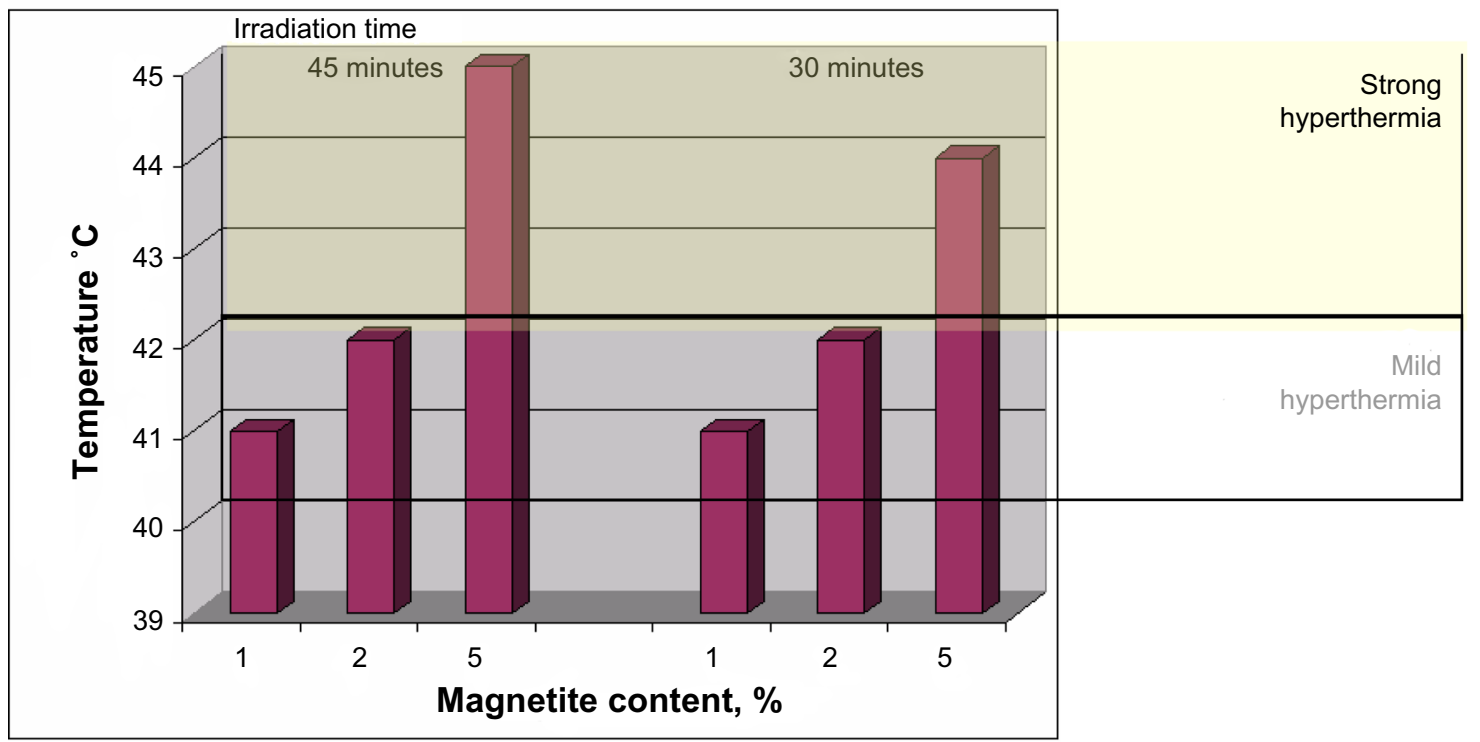

Figure 4 Hyperthermia versus content of magnetite.

Note: Data from Andronescu E et al. ${ }^{116}$

$80 \%$ for $100 \mu \mathrm{g} / \mathrm{mL} \mathrm{Fe}$, a value that is significantly higher than reported results obtained with other materials, which reach up to only $15 \%-20 \%$. The presence of silica led to a higher uptake of PC3 prostate cancer cells compared with pure magnetite. PC3 prostate cancer cell viability decreased once the content of Fe increased from 0 to $100 \mu \mathrm{g} / \mathrm{mL} .{ }^{191}$

Treating bone cancer with magnetite and/or magnetitebased materials has also been attempted with different materials, such as polymethyl methacrylate $/ \mathrm{Fe}_{3} \mathrm{O}_{4},{ }^{193,194}$ $\mathrm{HA} / \mathrm{Fe}_{3} \mathrm{O}_{4},{ }^{195-198}$ glass- and bioglass-based composites, ${ }^{199,200}$ and complex polymer/ceramic composite materials with various magnetite content. ${ }^{116,201,202}$ Based on the literature survey, most materials designed for bone cancer treatment by hyperthermia are based on calcium phosphates or bioglass and magnetite.

\section{Conclusion and perspectives}

Cancer remains the second-most common cause of death in the world, despite advances in prevention and early detection and newer treatment protocols. The development of new antitumoral agents as well as the development of more efficient treatment strategies are current pursuits for scientists. Chitosan and PEG have been intensively studied for drug delivery in many applications, including cancer treatment. Only a few papers have dealt with collagen-based support materials, most probably because of the high chemical sensibility of this protein in comparison with chitosan, PEG, alginate, etc. It is expected that the use of collagen for the preparation of drug-delivery systems of cytostatics will be continued in the future. Expected applications are bone cancer treatment by using composite materials based on collagen and calcium phosphates, skin cancer treatment by using collagen-based polymeric materials, or even colon cancer, collagen being a good carrier through the stomach.

\section{Acknowledgments}

The authors recognize financial support from the European Social Fund through the POSDRU/89/1.5/S/54785 project "Postdoctoral Program for Advanced Research in the Field of Nanomaterials". Catarina Marques thanks FCT for the fellowship grant (SFRH/BD/78355/2011). The support from CICECO, University of Aveiro, is also acknowledged.

\section{Disclosure}

The authors report no conflicts of interest in this work.

\section{References}

1. Fratzl P, Weinkamer R. Nature's hierarchical materials. Prog Mater Sci. 2007;52:1263-1334.

2. Silva CC, Thomazini D, Pinheiro AG, et al. Collagen-hydroxyapatite films: piezoelectric properties. Mat Sci Eng B Solid State Mater Adv Technol. 2001;86:210-218.

3. Noris-Suarez K, Lira-Olivares J, Ferreira AM, et al. In Vitro Deposition of Hydroxyapatite on Cortical Bone Collagen Stimulated by DeformationInduced Piezoelectricity. Biomacromolecules. 2007;8:941-948.

4. von Walterskirchen M. The U.S. Market for Medical Devices-Opportunities and Challenges for Swiss Companies. 2004. Available from: http:// www.swissbusinesshub.com/photos/news/SwissMedtech.pdf. Accessed January 7, 2014. 
5. Ficai M, Andronescu E, Ficai D, Voicu G, Ficai A. Synthesis and characterization of COLL-PVA/HA hybrid materials with stratified morphology. Colloids Surf B Biointerfaces. 2010;81:614-619.

6. Zhang LH, Tang PF, Zhang W, Xu M, Wang Y. Effect of Chitosan as a Dispersant on Collagen-Hydroxyapatite Composite Matrices. Tissue Eng Part C Methods. 2010;16:71-79.

7. Melville AJ, Rodriguez-Lorenzo LM, Forsythe JS, Gross KA. Drug delivery behaviour of hydroxyapatite and carbonated apatite. Bioceramics.2004;16:529-532.

8. Kim YH, Song BG, Kim SR, Kim KJ. Drug loaded porous hydroxyapatite and its in vitro release. Bioceramics. 2005;17:423-426.

9. Larena A, Caceres DA, Vicario C, Fuentes A. Release of a chitosanhydroxyapatite composite loaded with ibuprofen and acetyl-salicylic acid submitted to different sterilization treatments. Appl Surf Sci. 2004;238:518-522.

10. Park J, Lakes RS. Biomaterials: An introduction. New York: Springer; 2007.

11. Derner R, Anderson AC. The bone morphogenic protein. Clin Pediatric Med Surg. 2005;22:607-618.

12. Ficai A, Andronescu E, Voicu G, et al. Self assembled collagen/ hydroxyapatite composite materials. Chem Eng J. 2010;160:794-800.

13. Andronescu E, Voicu G, Ficai M, Mohora IA, Trusca R, Ficai A. Collagen/ hydroxyapatite composite materials with desired ceramic properties. J Electr Microscopy (Tokyo). 2011;60:253-259.

14. Ilie A, Andronescu E, Ficai D, et al. New approaches in layer by layer synthesis of collagen/hydroxyapatite composite materials. Cent Eur J Chem. 2011;9:283-289.

15. Vranceanu MD, Saban R, Antoniac I, Albu M, Miculescu F. Development and characterization of novel porous collagen based biocomposite for bone tissue regeneration. UPB Sci Bull, Series B. 2012;74:145-156.

16. Gallie WE, Toronto MB. The histrory of a bone graft. J Bone Joint Surg Am. 1914;s2-12:201-212.

17. Ashby M, Ferreira P, Schodek D, editors. Nanomaterials, Nanotechnologies and Design: An Introduction for Engineers and Architects. Amsterdam. Elsevier; 2009.

18. Chris Arts JJ, Verdonschot N, Schreurs BW, Buma P. The use of a bioresorbable nano-crystalline hydroxyapatite paste in acetabular bone impaction grafting. Biomaterials. 2006;27:1110-1118.

19. Rush SM. Bone graft substitutes: Osteobiologics. Clin Podiatr Med Surg. 2005;22:619-630.

20. Karageorgiou V, Kaplan D. Porosity of 3D biomaterial scaffolds and osteogenesis. Biomaterials. 2005;26:5474-5491.

21. Ficai A, Andronescu E, Trandafir V, Ghitulica C, Voicu G. Collagen/ hydroxyapatite composite obtained by electric field orientation. Mater Lett. 2010;64:541-544.

22. Ficai A, Andronescu E, Voicu G, Ghitulica C, Ficai D. The influence of collagen support and ionic species on the morphology of collagen/ hydroxyapatite composite materials. Mater Charact. 2010;61 402-407.

23. Ficai A, Andronescu E, Voicu G, Manzu D, Ficai M. Layer by layer deposition of hydroxyapatite onto the collagen matrix. Mat Sci Eng C Mater Biol Appl. 2009;29:2217-2220.

24. Wang H, Li Y, Zuo Y, Li J, Ma S, Cheng L. Biocompatibility and osteogenesis of biomimetic nano-hydroxyapatite/polyamide composite scaffolds for bone tissue engineering. Biomaterials. 2007;28:3338-3348.

25. Jiang D, Zhang J. Calcium phosphate with well controlled nanostructure for tissue engineering. Curr Appl Phys. 2009;9.

26. Rovira A, Amedee J, Bareille R, Rabaud M. Colonization of a calcium phosphate elastin-solubilized peptide-collagen composite material by human osteoblasts. Biomaterials. 1996;17:1535-1540.

27. Venugopal J, Prabhakaran MP, Zhang YZ, Low S, Choon AT, Ramakrishna S. Biomimetic hydroxyapatite-containing composite nanofibrous substrates for bone tissue engineering. Philos Trans A Math Phys Eng Sci. 2010;368:2065-2081.

28. Fratzl P, Gupta HS, Paschalis EP, Roschger P. Structure and mechanical quality of the collagen-mineral nano-composite in bone. JMater Chem. 2004; 14:2115-2123.
29. Murugan R, Ramakrishna S. Development of nanocomposites for bone grafting. Compos Sci Technol. 2005;65:2385-2406.

30. Ciobanu CS, Andronescu E, Vasile BS, Trusca R, Predoi D. Preliminary studies on hydroxyapatite doped with europium. UPB Sci Bull, Series B. 2011;73:63-70.

31. Dorozhkin SV. Nanosized and nanocrystalline calcium orthophosphates. Acta Biomater. 2010;6:715-734.

32. Dorozhkin SV. Bioceramics of calcium orthophosphates. Biomaterials. 2010;31:1465-1485.

33. Murugan R, Ramakrishna S. Bioresorbable composite bone paste using polysaccharide based nano hydroxyapatite. Biomaterials. 2004;25:3829-3835.

34. Ficai M, Andronescu E, Ficai A, Voicu G, Vasile BS. Poly Bis-GMA/ HA based hybrid composite materials. UPB Sci Bull, Series B. 2011;73:75-84.

35. Gloria A, De Santis R, Ambrosio L. Polymer-based composite scaffolds for tissue engineering. J Appl Biomater Biomech. 2010;8:57-67.

36. Rose FRAJ, Oreffo ROC. Bone tissue engineering: hope vs hype. Biochem Biophys Res Commun. 2002;292:1-7.

37. Scholz MS, Blanchfield JP, Bloom LD, et al. The use of composite materials in modern orthopaedic medicine and prosthetic devices: A review. Compos Sci Technol. 2011;71:1791-1803.

38. Marec-Berard P, Delafosse C, Foussat C. Cancer-related bone pain in children. Arch Pediatrie. 2005;12:191-198.

39. Mantyh P. The science behind metastatic bone pain. Eur J Cancer: Supplements. 2006;4:4-8.

40. Mercadante S. Malignant bone pain: pathophysiology and treatment. Pain.1997;69:1-18.

41. Cancer Research UK. Cancer worldwide - the global picture. 2008. Available from: http://www.cancerresearchuk.org/cancer-info/ cancerstats/world/the-global-picture. Accessed January 7, 2014.

42. Fotuh MA, Macary S. Factors affecting mechanical water shutoff. J Petrol Technol. 2001;53:58-59.

43. Ferlay J, Shin HR, Bray F, Forman D, Mathers C, Parkin DM, editors. Globocan 2008: Cancer Incidence and Mortality Worldwide. Lyon: International Agency for Research on Cancer; 2010.

44. Ries LAG, Eisner MP, Kosary CL, Hankey BF, Miller BA, Clegg L, Mariotto A, Feuer EJ, Edwards BK, editors. SEER Cancer Statistics Review, 1975-2001, National Cancer Institute. Bethesda, MD, http:// seer.cancer.gov/csr/1975_2001/; 2004.

45. Canadian Cancer Society. Canadian Cancer Statistics 2004. Toronto: National Cancer Institute of Canada; 2004.

46. Fraumeni JF Jr. Stature and malignant tumors of bone in childhood and adolescence. Cancer. 1967;20:967-973

47. Bleyer A, O'Leary M, Barr R, Ries L, editors. Cancer Epidemiology in Older Adolescents and Young Adults 15 to 29 Years of Age, Including SEER Incidence and Survival: 1975-2000. Bethesda (MD): National Cancer Institute; 2006.

48. Orentas R, Hodge JW, B. D. Johnson BD, editors. Cancer Vaccines and Tumor Immunity. Hoboken (NJ): John Wiley and Sons; 2008.

49. Purushotham S, Ramanujan RV. Thermoresponsive magnetic composite nanomaterials for multimodal cancer therapy. Acta Biomater. 2010;6:502-510.

50. Lubbe AS, Bergemann C, Huhnt W, et al. Preclinical experiences with magnetic drug targeting: Tolerance and efficacy. Cancer Res. 1996;56:4694-701.

51. Gupta R, Bajpai AK. Magnetically Guided Release of Ciprofloxacin from Superparamagnetic Polymer Nanocomposites. J Biomater Sci Polym Ed. 2011;22:893-918.

52. Xu R, Ma J, Sun XC, et al. Ag nanoparticles sensitize IR-induced killing of cancer cells. Cell Res. 2009;19:1031-1034.

53. Gallego Ó, Puntes V. What can nanotechnology do to fight cancer? Breast Cancer Res Treat. 2006;8:788-795.

54. Katti KV, Kannan R, Katti K, et al. Hybrid gold nanoparticles in molecular imaging and radiotherapy. Czechoslovak J Phys. 2006;56:D23-D34.

55. Tanaka T, Decuzzi P, Cristofanilli M, et al. Nanotechnology for breast cancer therapy. Biomed Microdevices. 2008. 
56. Liechty WB, Kryscio DR, Slaughter BV, Peppas NA. Polymers for Drug Delivery Systems. Annu Rev Chem Biomol Eng. 2010; $1: 149-173$.

57. Ghosh S, Ghosh S. Recent research and development in synthetic polymer-based drug delivery systems. Journal of Chemical Research. 2004;4:241-246.

58. Apicella A, Cappello B, Delnobile MA, et al. Poly(ethylene oxide)-based delivery systems. Polym Drugs Drug Adm. 1994;545:111-125.

59. Jackson JK, Min W, Cruz TF, et al. A polymer-based drug delivery system for the antineoplastic agent bis(maltolato)oxovanadium in mice. Br J Cancer. 1997;75(7):1014-1020.

60. Suzuki Y, Makino Y. Mucosal drug delivery using cellulose derivatives as a functional polymer. J Control Release. 1999;62 (1-2):101-107.

61. Aryal S, Hu CMJ, Zhang L. Polymer-cisplatin conjugate nanoparticles for acid-responsive drug delivery. ACS Nano. 2010;4(1):251-258.

62. Cafaggi S, Russo E, Stefani R, Leardi R, Caviglioli G, Parodi B, et al. Preparation and evaluation of nanoparticles made of chitosan or N-trimethyl chitosan and a cisplatin-alginate complex. $J$ Controll Release. 2007;121:110-123.

63. Han HD, Song CK, Park YS, et al. A chitosan hydrogel-based cancer drug delivery system exhibits synergistic antitumor effects by combining with a vaccinia viral vaccine. Int J Pharm. 2008;350:27-34.

64. Soo PL, Cho J, Grant J, Ho E, Picluette-Miller M, Allen C. Drug release mechanism of paclitaxel from a chitosan-lipid implant system: Effect of swelling, degradation and morphology. Eur J Pharm Biopharm. 2008;69:149-157.

65. Ta HT, Dass CR, Dunstan DE. Injectable chitosan hydrogels for localised cancer therapy. J Controll Release. 2008;126:205-216.

66. Junping W, Takayama K, Nagai T, Maitani Y. Pharmacokinetics and antitumor effects of vincristine carried by microemulsions composed of PEG-lipid, oleic acid, vitamin E and cholesterol. Int J Pharm. 2003;251(1-2):13-21.

67. Kiefer MV, Albert M, McNally, M et al. Chemoembolization of intrahepatic cholangiocarcinoma with cisplatinum, doxorubicin, mitomycin C, ethiodol, and polyvinyl alcohol: a 2-center study. Cancer. 2011;117(7):1498-1505.

68. Armentano I, Dottori M, Fortunati E, Mattioli S, Kenny JM. Biodegradable polymer matrix nanocomposites for tissue engineering: A review. Polym Degrad Stab. 2010;95:2126-2146.

69. Albu MG, Ghica MV, Ficai A, Titorencu I, Popa L. Influence of Freeze-Drying Process on Porosity and Kinetics Release of CollagenDoxycycline Matrices. Proceedings of the 3rd International Conference on Advanced Materials and Systems. 2010:181-186.

70. Andronescu E, Ficai A, Georgiana M, et al. Collagen-hydroxyapatite/ Cisplatin Drug Delivery Systems for Locoregional Treatment of Bone Cancer. Technol Cancer Res Treat. 2013;12:275-284.

71. Titorencu I, Albu MG, Popa L, et al. Collagen-Doxycycline Matrices Used in Tissue Engineering. Farmacia. 2011;59:794-802.

72. Kayal S, Ramanujan RV. Doxorubicin loaded PVA coated iron oxide nanoparticles for targeted drug delivery. Mat Sci Eng C Mater Biol Appl. 2010;30:484-490.

73. Jadhav KR, Pacharane SS, Koshy PV, Kadam VJ. Smart polymers and their role in drug delivery: A review. Curr Drug Ther. 2010;5: 250-261.

74. Medeiros SF, Santos AM, Fessi H, Elaissari A. Stimuli-responsive magnetic particles for biomedical applications. Int $J$ Pharm. 2011;403:139-161.

75. Genin FY, Luo P, Dash AK, inventors. Berkeley Advanced Biomaterials, Inc., assignee. Hydroxyapatite based drug delivery implant for cancer treatment. United States patent US 6767550 B1. July 30, 2004.

76. Schegg B, Hülsmeier AJ, Rutschmann C, Maag C, Hennet T. Core glycosylation of collagen Is initiated by two $\beta(1-\mathrm{O})$ galactosyltransferases. Mol Cell Biol. 2009;29(4):943-952.

77. Albu MG, Titorencu I, Ghica MV. Collagen gels and matrices for biomedical applications. In: Pignatello R, editor. Biomaterials Applications for Nanomedicine. Rijeka, Croatia: InTech: 2011.
78. Albu MG, Titorencu I, Ghica MV. Collagen-based Drug Delivery Systems for Tissue Engineering. In: Pignatello R, editor. Biomaterials Applications for Nanomedicine. Rijeka, Croatia: InTech; 2011.

79. Nagai T, Suzuki N. Isolation of collagen from fish waste materialskin, bone and fins. Food Chem. 2000;68:277-281.

80. Miller EJ, Martin GR, Piez KA, Powers MJ. Characterization of Chick Bone Collagen and Compositional Changes Associated with Maturation. J Biol Chem. 1967;242:5481-5489.

81. Castro-Cesena AB, Novitskaya EE, Phadke A, Varghese S, McKittrick J. Isolation of Collagen from Cortical Bovine Bone for Preparation of Porous Collagen Sponges. Mechanics of Biological Systems and Materials, Conference Proceedings of the Society for Experimental Mechanics Series. 2013:73-78.

82. Kuboki Y, Shimokawa H, Ono T, Sasaki S. Detection of collagen degradation products in bone. Calcif Tissue Res. 1973;12:303-312.

83. Singh O, Gupta SS, Soni M, Moses S, Shukla S, Mathur RK. Collagen dressing versus conventional dressings in burn and chronic wounds: a retrospective study. J Cutan Aesthet Surg. 2011;4(1):12-16.

84. Klein MB, Engrav LH, Holmes JH, et al. Management of facial burns with a collagen/glycosaminoglycan skin substitute-prospective experience with 12 consecutive patients with large, deep facial burns. Burns. 2005;31(3):257-261.

85. Aust MC, Fernandes D, Kolokythas P, Kaplan HM, Vogt PM. Percutaneous collagen induction therapy: an alternative treatment for scars, wrinkles, and skin laxity. Plast Reconstr Surg. 2008;121(4):1421-1429.

86. Albu MG. Collagen gels and matrices for biomedical applications: Lambert Academic Publishing: Saarbrücken; 2011.

87. Albu MG, Trandafir V, Suflet DM, Chitanu GC, Budrugeac P, Titorencu I. Biocomposites based on collagen and phosphorylated dextran for bone regeneration. J Mater Res. 2012;27:1086-1096.

88. Phienney RB, Schwartz SD, Lee DA, Mondino BJ. Collagen-shields delivery of gentamicin and vancomycin. Arch Ophtalmol. 1988;106 1599-1604.

89. Ruszczak Z, Friess W. Collagen as a carrier for on-site delivery of antibacterial drugs. Adv Drug Deliv Rev. 2003;55:1679-1698.

90. Bandyopadhyay-Ghosh S. Bone as a Collagen-hydroxyapatite Composite and its Repair. Trends Biomater Artif Organs. 2008;22:112-120.

91. Lickorish D, Ramshaw JAM, Werkmeister JA, Glattauer V, Howlett CR. Collagen-hydroxyapatite composite prepared by biomimetic process. J Biomed Mater Res A. 2004;68A:19-27.

92. Kikuchi M, Itoh S, Ichinose S, Shinomiya K, Tanaka J. Selforganization mechanism in a bone-like hydroxyapatite/collagen nanocomposite synthesized in vitro and its biological reaction in vivo. Biomaterials. 2001;22:1705-1711.

93. Cui F-Z, LiY, Ge J. Self-assembly of mineralized collagen composites. Mater Sci Eng R Rep. 2007;57:1-27.

94. Ficai A, Andronescu E, Ficai D, Sonmez M, Albu MG, Voicu G. Mimicking the morphology of long bone. Cent Eur J Chem. 2012;10:1949-1953.

95. Wahl DA, Czernuszka JT. Collagen-hydroxyapatite composites for hard tissue repair. Eur Cell Mater. 2006;11:43-56.

96. Habraken WJ, Wolke JG, Jansen JA. Ceramic composites as matrices and scaffolds for drug delivery in tissue engineering. Adv Drug Deliv Rev. 2007;59(4-5):234-248.

97. Dorozhkin SV. Amorphous calcium (ortho)phosphates. Acta Biomater. 2010;6:4457-4475.

98. Girones Molera J, Mendez JA, San Roman J. Bioresorbable and nonresorbable polymers for bone tissue engineering. Curr Pharm Des. 2012;18(18):2536-2557.

99. Beachley V, Katsanevakis E, Zhang N, Wen XJ. Highly aligned polymer nanofiber structures: fabrication and applications in tissue engineering. In: Jayakumar R, Nair SV, editors. Biomedical Applications of Polymeric Nanofibers. Vol 246. Heidelberg: Springer; 2012:171-212.

100. Tien WB, Chen MT, Yao PC. Effects of pH and temperature on microstructure and morphology of hydroxyapatite/collagen composites synthesized in vitro. Mater Sci Eng C Mater Biol Appl. 2012;32:2096-2102. 
101. Sang L, Huang J, Luo DM, Chen ZH, Li XD. Bone-like nanocomposites based on self-assembled protein-based matrices with $\mathrm{Ca} 2+$ capturing capability. J Mater Sci Mater Med. 2010;21:2561-2568.

102. Swetha M, Sahithi K, Moorthi A, Srinivasan N, Ramasamy K, Selvamurugan N. Biocomposites containing natural polymers and hydroxyapatite for bone tissue engineering. Int J Biol Macromol. 2010;47(1):1-4.

103. Szpalski C, Wetterau M, Barr J, Warren SM. Bone tissue engineering: current strategies and techniques-part I: Scaffolds. Tissue Eng Part B Rev. 2012;18(4):246-257.

104. Gardin C, Ferroni L, Favero L et al. Nanostructured biomaterials for tissue engineered bone tissue reconstruction. Int J Mol Sci. 2012;13(1):737-757.

105. Khan F, Dahman Y. A novel approach for the utilization of biocellulose nanofibres in polyurethane nanocomposites for potential applications in bone tissue implants. Des Monomers Polym. 2012;15(1):1-29.

106. Canal C, Ginebra MP. Fibre-reinforced calcium phosphate cements: a review. J Mech Behav Biomed Mater. 2011;4(8):1658-1671.

107. Wagoner Johnson AJ, Herschler BA. A review of the mechanical behavior of $\mathrm{CaP}$ and $\mathrm{CaP} /$ polymer composites for applications in bone replacement and repair. Acta Biomater. 2011;7(1):16-30.

108. Chiara G, Letizia F, Lorenzo F, et al. Nanostructured biomaterials for tissue engineered bone tissue reconstruction. Int $\mathrm{J} \mathrm{Mol} \mathrm{Sci}$. 2012;13;737-757.

109. Otsuka M, Hirano R. Bone cell activity responsive drug release from biodegradable apatite/collagen nano-composite cements-In vitro dissolution medium responsive vitamin K2 release. Colloids Surface B Biointerfaces.2011;85:338-342.

110. Wang G, Mostafa NZ, Incani V, Kucharski C, Uludag H. Bisphosphonate-decorated lipid nanoparticles designed as drug carriers for bone diseases. J Biomed Mater Res A. 2012;100(3):684-693.

111. Tsourvakas S. Local antibiotic therapy in the treatment of bone and soft tissue infections. In: Danilla S, editor. Selected topics in plastic reconstructive surgery. Rijeka, Croatia: InTech; 2012:17-44.

112. Martins VC, Goissis G, Ribeiro AC, Marcantônio E Jr, Bet MR. The controlled release of antibiotic by hydroxyapatite: anionic collagen composites. Artif Organs. 1998;22(3):215-221.

113. Amaro Martins VC, Goissis G. Nonstoichiometric hydroxyapatiteanionic collagen composite as support for the double sustained release of gentamicin and orfloxacin/ciprofloxacin. Artif Organs. 2000;24(3):224-230.

114. Golub LM. Special Issue: Clinical Applications of Non-Antbacterial Tetracyclines Introduction. Pharmacol Res. 2011;63:99-101.

115. Ficai A, Andronescu E, Voicu G, Albu MG, Ilie A. Biomimetically synthesis of collagen/hydroxyapatite composite materials. Mat Plast. 2010;47:205-208.

116. Andronescu E, Ficai M, Voicu G, Ficai D, Maganu M, Ficai A. Synthesis and characterization of collagen/hydroxyapatite:magnetite composite material for bone cancer treatment. J Mater Sci-Mater M. 2010;21:2237-2242.

117. Ficai A, Andronescu E, Ghitulica C, et al. Colagen/Hydroxyapatite Interactions in Composite Biomaterials. Mat Plast. 2009;46:11-15.

118. Liu X, Zhao M, Lu J, Ma J, Wei J, Wei S. Cell responses to two kinds of nanohydroxyapatite with different sizes and crystallinities. Int $J$ Nanomed. 2012; 7:1239-1250.

119. Galois L, Mainard D. Bone ingrowth into two porous ceramics with different pore sizes: An experimental study. Acta Orthop Belg. 2004;70:598-603.

120. Yunoki S, Ikoma T, Monkawa A, et al. Control of pore structure and mechanical property in hydroxyapatite/collagen composite using unidirectional ice growth. Mater Lett. 2006;60:999-1002.

121. Yunoki S, Ikoma T, Tsuchiya A, et al. Fabrication and mechanical and tissue ingrowth properties of unidirectionally porous hydroxyapatite/collagen composite. J Biomed Mater Res B. 2007;80B:166-173.

122. Soundrapandian C, Sa B, Datta S. Organic-inorganic composites for bone drug delivery. Aaps Pharmscitech. 2009;10:1158-1171.
123. Venugopal J, Prabhakaran MP, Low S, et al. Nanotechnology for nanomedicine and delivery of drugs. Curr Pharm Design. 2008; 14:2184-2200.

124. Sanders WE, Sanders CC. Toxicity of Antibacterial Agents: Mechanism of Action on Mammalian Cells. Anпu Rev Pharmacol. 1979;19:53-83.

125. Lichter JA, Van Vliet KJ, Rubner MF. Design of antibacterial surfaces and interfaces: Polyelectrolyte multilayers as a multifunctional platform. Macromolecules. 2009;42(22):8573-8586.

126. Schottner G. Hybrid sol-gel-derived polymers: Applications of multifunctional materials. Chem. Mater. 2001;13(10):3422-3435.

127. Kaito T, Myoui A, Saito N et al. Potentiation of the activity of bone morphogenetic protein-2 in bone regeneration by a PLA-PEG/ hydroxyapatite composite. Biomaterials. 2005;26(1):73-79.

128. Feng B, Hu DX, Zhang YD. Accelerated Bone Regeneration by Chitosan/Nanometer Hydroxyapatite/Collagen Composite Incorporating BMP-7 Mimetic Peptide. J Hard Tissue Biol. 2012;21:481-487.

129. Li JF, Lin ZY, Zheng QX et al. Repair of rabbit radial bone defects using true bone ceramics combined with BMP-2-related peptide and type I collagen. Mater Sci Eng C Mater Biol Appl. 2010;30(8):1272-1279.

130. Liu LR, Zhang LH, Wang FJ, Zhang QQ. The study of collagen-HA composite with incorporated BMP as bone tissue engineering scaffold. In: Zhang XD, editor. Advanced Biomaterials VI: ASBM6: Proceedings of the 6th Asian Symposium on Biomedical Materials, Emei, Chengdu, China, July 19-22, 2004. Dürnten, Switzerland: Trans Tech; 2005:261-264.

131. Sotome S, Uemura T, Kikuchi M, Chen J, Itoh S, Tanaka J, et al. Synthesis and in vivo evaluation of a novel hydroxyapatite/collagenalginate as a bone filler and a drug delivery carrier of bone morphogenetic protein. Materials Science \& Engineering C-Biomimetic and Supramolecular Systems. 2004;24(3):341-347.

132. Otsuka M, Kuninaga T, Otsuka K, Higuchi WI. Effect of nanostructure on biodegradation behaviors of self-setting apatite/collagen composite cements containing vitamin $\mathrm{K} 2$ in rats. J Biomed Mater Res B Appl Biomater. 2006;79(1):176-184.

133. Wang G, Babadagli ME, Uludag H. Bisphosphonate-derivatized liposomes to control drug release from collagen/hydroxyapatite scaffolds. Mol Pharm. 2011;8(4):1025-1034.

134. Ficai A, Andronescu E, Ghitulica CD, Ficai D, Voicu G, Albu MG. Process for preparing multifunctional composite materials with possible applicability in the treatment of bone cancer, RO 2010 $0001171 / 20101124$.

135. Tu J, Yu M, Lu Y et al. Preparation and antibiotic drug release of mineralized collagen coatings on titanium. J Mater Sci Mater Med. 2012;23(10):2413-2423

136. Robinson DH, Mauger JW. Drug delivery systems. Am J Hosp Pharm. 1991;48(10):S14-23.

137. Szasz M, Hajdu M, Pesti N et al. In Vitro Efficiency of Vancomycin Containing Experimental Drug Delivery Systems. Acta Microbiol Immunol Hung. 2013;60(4):461-468.

138. Zhang F, Wu J, Kang D, Zhang HB. Development of a complex hydrogel of hyaluronan and PVA embedded with silver nanoparticles and its facile studies on Escherichia coli. J Biomat Sci-Polym E. 2013;24:1410-1425.

139. Wadajkar AS, Bhavsar Z, Ko CY et al. Multifunctional particles for melanoma-targeted drug delivery. Acta Biomater. 2012;8(8):2996-3004.

140. Ruel-Gariepy E, Shive M, Bichara A, et al. A thermosensitive chitosanbased hydrogel for the local delivery of paclitaxel. Eur J Pharm Biopharm. 2004;57:53-63.

141. Nagarajan S, Reddy BS, Tsibouklis J. In vitro effect on cancer cells: synthesis and preparation of polyurethane membranes for controlled delivery of curcumin. J Biomed Mater Res A. 2011;99:410-417.

142. Kim S, Liu Y, Gaber MW, Bumgardner JD, Haggard WO, Yang Y. Development of chitosan-ellagic acid films as a local drug delivery system to induce apoptotic death of human melanoma cells. J Biomed Mater Res B Appl Biomater. 2009;90(1):145-155.

143. Dhanikula AB, Panchagnula R. Localized paclitaxel delivery. Int $J$ Pharm. 1999;183:85-100. 
144. Fukushima S, Machida M, Akutsu T, et al. Roles of adriamycin and adriamycin dimer in antitumor activity of the polymeric micelle carrier system. Colloid Surfaces B. 1999;16:227-236.

145. Fan HY, Dash AK. Effect of cross-linking on the in vitro release kinetics of doxorubicin from gelatin un-plants. Int J Pharm. 2001;213:103-116.

146. Iafisco M, Palazzo B, Marchetti M et al. Smart delivery of antitumoral platinum complexes from biomimetic hydroxyapatite nanocrystals. J Mater Chem. 2009; 19:8385-8392.

147. Netz DJA, Sepulveda P, Pandolfelli VC, et al. Potential use of gelcasting hydroxyapatite porous ceramic as an implantable drug delivery system. Int J Pharm. 2001;213:117-125.

148. Baino F. Biomaterials and implants for orbital floor repair. Acta Biomater. 2011;7:3248-3266.

149. Dorozhkin SV. Calcium Orthophosphate-Based Bioceramics. Materials. 2013;6:3840-3942.

150. Tardei C, Spataru M, Albu FM, Stoleriu S, Ioncea A. Fabrication and Characterization of Porous Tri-Calcium Phosphate Ceramic Microspheres. Rev Rom Mater. 2013;43:41-47. Romanian.

151. Uchida A, Shinto Y, Araki N, Ono K. Slow Release of Anticancer Drugs from Porous Calcium Hydroxyapatite Ceramic. J Orthop Res. 1992;10:440-445.

152. Palazzo B, Iafisco M, Laforgia M, et al. Biomimetic hydroxyapatitedrug nanocrystals as potential bone substitutes with antitumor drug delivery properties. Adv Funct Mater. 2007;17:2180-2188.

153. Barroug A, Glimcher MJ. Hydroxyapatite crystals as a local delivery system for cisplatin: adsorption and release of cisplatin in vitro. J Orthop Res. 2002;20(2):274-280.

154. Iafisco M, Margiotta N. Silica xerogels and hydroxyapatite nanocrystals for the local delivery of platinum-bisphosphonate complexes in the treatment of bone tumors: A mini-review. J Inorg Biochem. 2012;117:237-247.

155. Niu XF, Feng QL, Wang MB, Guo XD, Zheng QX. Porous nano-HA/ collagen/PLLA scaffold containing chitosan microspheres for controlled delivery of synthetic peptide derived from BMP-2. J Control Release. 2009;134:111-117.

156. Sotome S, Uemura T, Kikuchi M, et al. Synthesis and in vivo evaluation of a novel hydroxyapatite/collagen-alginate as a bone filler and a drug delivery carrier of bone morphogenetic protein. Mat Sci Eng C-Bio S. 2004;24:341-347.

157. Visser R, Arrabal PM, Becerra J, Rinas U, Cifuentes M. The effect of an rhBMP-2 absorbable collagen sponge-targeted system on bone formation in vivo. Biomaterials. 2009;30(11):2032-2037.

158. Valimaki VV, Aro HT. Molecular basis for action of bioactive glasses as bone graft substitute. Scand J Surg. 2006;95:95-102.

159. Papapoulos SE. The role of bisphosphonates in the prevention and treatment of osteoporosis. Am J Med. 1993;95(5A):48S-52S.

160. Titorencu I, Albu MG, Anton F, Georgescu A, Jinga VV. Collagendexamethasone and collagen-D3 scaffolds for bone tissue engineering. Mol Cryst Liq Cryst. 2012;555(1):208-217.

161. Zou Q, Li YB, Zhang L, Zuo Y, Li JF, Li JD. Antibiotic delivery system using nano-hydroxyapatite/chitosan bone cement consisting of berberine. J Biomed Mater Res A. 2009;89A:1108-1117.

162. Chen T, Wang R, Xu LQ, Neoh KG, Kang ET. Carboxymethyl chitosanfunctionalized magnetic nanoparticles for disruption of biofilms of Staphylococcus aureus and Escherichia coli. Ind Eng Chem Res. 2012;51:13164-172.

163. Tanaka K, Ito A, Kobayashi T, et al. Intratumoral injection of immature dendritic cells enhances antitumor effect of hyperthermia using magnetic nanoparticles. Int J Cancer. 2005;116:624-633.

164. Di Marco M, Sadun C, Port M, Guilbert I, Couvreur P, Dubernet C. Physicochemical characterization of ultrasmall superparamagnetic iron oxide particles (USPIO) for biomedical application as MRI contrast agents. Int J Nanomedicine. 2007;2(4):609-622.

165. Mahmoudi M, Simchi A, Imani M, Milani AS, Stroeve P. Optimal design and characterization of superparamagnetic iron oxide nanoparticles coated with polyvinyl alcohol for targeted delivery and imaging. J Phys Chem B. 2008;112(46):14470-14481.
166. Arias JL, Reddy LH, Couvreur P. Magnetoresponsive squalenoyl gemcitabine composite nanoparticles for cancer active targeting. Langmuir. 2008;24(14):7512-7519.

167. Guo S, Li D, Zhang L, Li J, Wang E. Monodisperse mesoporous superparamagnetic single-crystal magnetite nanoparticles for drug delivery. Biomaterials. 2009;30(10):1881-1889.

168. An J, Yuan XY, Luo QZ, Wang DS. Preparation of chitosan-graft(methyl methacrylate)/Ag nanocomposite with antimicrobial activity. Polymer International. 2010;59(1):62-70.

169. Sahni G, Gopinath P, Jeevanandam P. A novel thermal decomposition approach to synthesize hydroxyapatite-silver nanocomposites and their antibacterial action against GFP-expressing antibiotic resistant E. coli. Colloids Surf B Biointerfaces. 2013;103:441-447.

170. Samani S, Hossainalipour SM, Tamizifar M, Rezaie HR. In vitro antibacterial evaluation of sol-gel-derived $\mathrm{Zn}-, \mathrm{Ag}-$, and ( $\mathrm{Zn}$ $+\mathrm{Ag}$ )-doped hydroxyapatite coatings against methicillin-resistant Staphylococcus aureus. J Biomed Mater Res A. 2013;101(1): 222-230.

171. Torres N, Oh S, Appleford M, Dean DD et al. Stability of antibacterial self-assembled monolayers on hydroxyapatite. Acta Biomater. 2010;6(8):3242-3255.

172. Nedelcu I-A, Ficai A, Sonmez M, Ficai D, Oprea O, Andronescu E. Silver based materials for biomedical applications. Curr Org Chem. 2014;18(4):173-182.

173. Bagi CM. Targeting of therapeutic agents to bone to treat metastatic cancer. Adv Drug Deliver Rev. 2005;57:995-1010.

174. Porter JR, Ruckh TT, Popat KC. Bone Tissue Engineering: A Review in Bone Biomimetics and Drug Delivery Strategies. Biotechnol Progr.2009;25:1539-1560.

175. Dass CR, Ek ETH, Choong PFM. Human xenograft osteosarcoma models with spontaneous metastasis in mice: clinical relevance and applicability for drug testing. J Cancer Res Clin Oncol. 2007;133(3):193-198.

176. Chang $\mathrm{CH}$, Kuo TF, Lin CC, et al. Tissue engineering-based cartilage repair with allogenous chondrocytes and gelatin-chondroitinhyaluronan tri-copolymer scaffold: A porcine model assessed at 18, 24, and 36 weeks. Biomaterials. 2006;27:1876-1888.

177. Venkatesan J, Pallela R, Bhatnagar I, Kim SK. Chitosan-amylopectin/ hydroxyapatite and chitosan-chondroitin sulphate/hydroxyapatite composite scaffolds for bone tissue engineering. Int J Biol Macromol. 2012;51(5):1033-1042.

178. Itokazu M, Esaki M, Yamamoto K, Tanemori T, Kasai T. Local drug delivery system using ceramics: vacuum method for impregnating a chemotherapeutic agent into a porous hydroxyapatite block. J Mater Sci-Mater M. 1999;10(4):249-252.

179. Itokazu M, Kumazawa S, Wada E, Wenyi Y. Sustained release of adriamycin from implanted hydroxyapatite blocks for the treatment of experimental osteogenic sarcoma in mice. Cancer Lett. 1996;107(1):11-18.

180. Itokazu M, Sugiyama T, Ohno T, Wada E, Katagiri Y. Development of porous apatite ceramic for local delivery of chemotherapeutic agents. J Biomed Mater Res. 1998;39(4):536-538.

181. Carrle D, Bielack SS. Current strategies of chemotherapy in osteosarcoma. Int Orthop. 2006;30:445-451.

182. Luger N, Mach D, Sevcik M, Mantyh P. Bone cancer pain: from model to mechanism to therapy. J Pain Symptom Manage. 2005;29:S32-46.

183. Foley KM. Advances in Cancer Pain. Arch Neurol. 1999;56: 413-417.

184. The Bone and Cancer Foundation. Managing Pain Related to Cancer and Bone. New York: Bone and Cancer Foundation 2011.

185. Bone and Cancer Foundation. Managing Pain Related to Cancer and Bone. New York: Bone and Cancer Foundation; 2011.

186. Pharo GH, Zhou L. Pharmacologic management of cancer pain. JAm Osteopath Assoc. 2005;105:S21-S28.

187. Nersesyan H, Slavin KV. Current approach to cancer pain management: availability and implications of different treatment options. Ther Clin Risk Manag. 2007;3(3):381-400. 
188. Grumezescu AM, Andronescu E, Ficai A et al. Synthesis, characterization and biological evaluation of a Fe3O4/C12 core/shell nanosystem. Lett Appl Nanobioscience. 2012;1:31-35.

189. Jadhav SA, Bongiovanni R. Synthesis and organic functionalization approaches for magnetite (Fe3O4) nanoparticles. Adv Mater Lett. 2012;3(5):356-361.

190. Lacroix LM, Carrey J, Respaud M. A frequency-adjustable electromagnet for hyperthermia measurements on magnetic nanoparticles. Rev Sci Instrum. 2008;79(9):093909.

191. Kowal CD, Bertino JR. Possible benefits of hyperthermia to chemotherapy. Cancer Res. 1979;39(6):2285-2289.

192. Campbell JL, Arora J, Cowell SF et al. Quasi-cubic magnetite/silica core-shell nanoparticles as enhanced MRI contrast agents for cancer imaging. PLoS One. 2011;6:e21857.

193. Kawashita M, Kawamura K, Li Z. PMMA-based bone cements containing magnetite particles for the hyperthermia of cancer. Acta Biomater. 2010;6(8):3187-3192.

194. Li Z, Kawamura K, Kawashita M, Kudo TA, Kanetaka H, Hiraoka M. In vitro assessment of poly(methylmethacrylate)-based bone cement containing magnetite nanoparticles for hyperthermia treatment of bone tumor. J Biomed Mater Res A. 2012;100(10):2537-2545.

195. Tampieri A, D'Alessandro T, Sandri M et al. Intrinsic magnetism and hyperthermia in bioactive Fe-doped hydroxyapatite. Acta Biomater. 2012;8(2):843-851.
196. Singh RK, El-Fiqi AM, Patel KD, Kim HW. A novel preparation of magnetic hydroxyapatite nanotubes. Mater Lett. 2012;75:130-133.

197. Gopi D, Ansari MT, Shinyjoy E, Kavitha L. Synthesis and spectroscopic characterization of magnetic hydroxyapatite nanocomposite using ultrasonic irradiation. Spectrochim Acta A Mol Biomol Spectrosc. 2012;87:245-250.

198. Murakami S, Hosono T, Jeyadevan B, Kamitakahara M, Ioku K. Hydrothermal synthesis of magnetite/hydroxyapatite composite material for hyperthermia therapy for bone cancer. J Ceram Soc Jpn. 2008;116(1357):950-954.

199. Singh RK, Srinivasan A, Kothiyal GP. Evaluation of CaO-SiO2-P2O5 -Na2O-Fe2O3 bioglass-ceramics for hyperthermia application. JMater Sci Mater Med. 2009;20 Suppl 1:S147-S151.

200. O. Bretcanu, E. Verne, Bioactive ferrimagnetic glass-ceramics for magnetic induction hyperthermia. In: NanoScience and Technology Institute, editor. Technical Proceedings of the 2005 NSTI Nanotechnology Conference and Trade Show. Boca Raton (F1): CRC; 2005:266-269.

201. Beherei HH, Abdel-Aal MS, Shaltout AA, El-Magharby A. Biophysiochemical characterization of anticancer nano-ceramic polymer scaffold for bone grafting. Pharma Chem. 2012;4(1): 544-551.

202. Kokubo T. Preparation and properties of composite ceramics for biomedical applications. J Jpn Soc Powder Powder Metall. 1990;37: 324-328. Japanese.
International Journal of Nanomedicine

\section{Publish your work in this journal}

The International Journal of Nanomedicine is an international, peerreviewed journal focusing on the application of nanotechnology in diagnostics, therapeutics, and drug delivery systems throughout the biomedical field. This journal is indexed on PubMed Central,

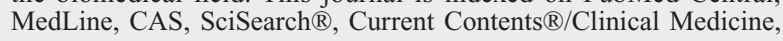

\section{Dovepress}

Journal Citation Reports/Science Edition, EMBase, Scopus and the Elsevier Bibliographic databases. The manuscript management system is completely online and includes a very quick and fair peer-review system, which is all easy to use. Visit http://www.dovepress.com/ testimonials.php to read real quotes from published authors. 